\title{
Short-term Training is Accompanied by a Down Regulation of ACC2 mRNA in Skeletal Muscle
}

Citation for published version (APA):

Schrauwen-Hinderling, V. B., Hesselink, M. K., Moonen-Kornips, C. F., Schaart, G., Kooi, M. E., Saris, W. H., \& Schrauwen, P. (2006). Short-term Training is Accompanied by a Down Regulation of ACC2 mRNA in Skeletal Muscle. International Journal of Sports Medicine, 27(10), 786-791. https://doi.org/10.1055/s2005-873020

Document status and date:

Published: 01/01/2006

DOI:

10.1055/s-2005-873020

Document Version:

Publisher's PDF, also known as Version of record

Document license:

Taverne

Please check the document version of this publication:

- A submitted manuscript is the version of the article upon submission and before peer-review. There can be important differences between the submitted version and the official published version of record.

People interested in the research are advised to contact the author for the final version of the publication, or visit the DOI to the publisher's website.

- The final author version and the galley proof are versions of the publication after peer review.

- The final published version features the final layout of the paper including the volume, issue and page numbers.

Link to publication

\footnotetext{
General rights rights.

- You may freely distribute the URL identifying the publication in the public portal. please follow below link for the End User Agreement:

www.umlib.nl/taverne-license

Take down policy

If you believe that this document breaches copyright please contact us at:

repository@maastrichtuniversity.nl

providing details and we will investigate your claim.
}

Copyright and moral rights for the publications made accessible in the public portal are retained by the authors and/or other copyright owners and it is a condition of accessing publications that users recognise and abide by the legal requirements associated with these

- Users may download and print one copy of any publication from the public portal for the purpose of private study or research.

- You may not further distribute the material or use it for any profit-making activity or commercial gain

If the publication is distributed under the terms of Article $25 \mathrm{fa}$ of the Dutch Copyright Act, indicated by the "Taverne" license above, 


\title{
Short-term Training is Accompanied by a Down Regulation of ACC2 mRNA in Skeletal Muscle
}

\author{
V. B. Schrauwen-Hinderling ${ }^{1,2,5}$ \\ M. K. C. Hesselink ${ }^{2,4}$ \\ E. Moonen-Kornips ${ }^{2,3}$ \\ G. Schaart ${ }^{2,4}$ \\ M. E. Kooi ${ }^{1}$ \\ W. H. M. Saris 2,3 \\ P. Schrauwen ${ }^{2,3}$
}

\begin{abstract}
Recently, we showed that short-term training induced a rapid increase in IMCL whilst insulin sensitivity tended to improve. Here we investigate molecular adaptations accompanying this physiological training-induced accumulation of IMCL. Nine untrained men (age: $23.3 \pm 3.2 \mathrm{y}$; maximal power output: $3.8 \pm 0.6 \mathrm{~W} / \mathrm{kg}$ body weight) trained for two weeks. Before and after training, subjects cycled for three hours and biopsies were taken before and after exercise. mRNA concentrations of ACC2, HSL, LPL, Glut4 and HKII were quantified by RT-PCR and association of Glut4 with the membrane was quantified by immunohistochemical method. Endurance training resulted in a decrease of $29.1 \%$ in ACC2 mRNA ( $p=0.02)$. After training, ACC2 mRNA tended to decrease with acute exercise $(-24.4 \%[\mathrm{p}=0.06])$. HSL mRNA decreased with acute exercise after training $(-37.3 \%[p=0.002])$.
\end{abstract}

LPL mRNA concentrations increased with acute exercise before training $(+42.4 \%[\mathrm{p}=0.05])$ and HKII mRNA increased with acute exercise before $(+72.5 \%[\mathrm{p}=0.025])$ and after training $(+99.3 \%$ $[p=0.05]$ ). After acute exercise, more Glut 4 was associated with the membrane than before exercise, but it was not affected by training. We conclude that the training-induced increase in IMCL was accompanied by molecular adaptations in muscle to improve fat oxidative capacity, while markers of glucose metabolism were not yet changed. The present data are in line with the hypothesis that the fat oxidative capacity might be more important than the IMCL content in determining insulin sensitivity.

\section{Key words}

Insulin sensitivity · fat oxidative capacity · intramuscular triglycerides (IMTG) · skeletal muscle

\section{Introduction}

High intramyocellular lipid content has been associated with insulin resistance $[16,23,27,34]$. However, paradoxically, endurance trained athletes are also characterized by high IMCL levels $[13,19]$ while being highly insulin-sensitive, suggesting that the relation is not causal. Based on cross-sectional data, comparing trained athletes with untrained subjects, a negative effect of in- tramuscular triglycerides themselves on insulin sensitivity can, however, not be ruled out, as it would be conceivable that other long term metabolic adaptations to training overcompensate negative effects of enlarged intramuscular triglyceride depots. Long term endurance training leads to many physiological adaptations such as increased capillary supply [22], increased fat free mass and increased number of type I fibers [6] and increased fat oxidative capacity [31] which all have recognized positive effects

Affiliation

${ }^{1}$ Department of Radiology, University Hospital Maastricht, Maastricht, The Netherlands

${ }^{2}$ Nutrition and Toxicology Research Institute Maastricht, NUTRIM, Maastricht University, Maastricht,

The Netherlands

${ }^{3}$ Department of Human Biology, Maastricht University, Maastricht, The Netherlands

${ }^{4}$ Department of Movement Sciences, Maastricht University, Maastricht, The Netherlands

${ }^{5}$ Department of Biomedical Engineering, Eindhoven University of Technology, Eindhoven, The Netherlands

Correspondence

Vera B. Schrauwen-Hinderling · Department of Radiology, University Hospital Maastricht · P. O. Box 5800 . 6202 AZ Maastricht · The Netherlands · Phone: + 31433874951/10 · Fax: + 31433876909 .

E-mail: vhi@rdia.azm.nl

Accepted after revision: September 20, 2005

Bibliography

Int J Sports Med 2006; 27: 786 - 791 @ Georg Thieme Verlag KG · Stuttgart · New York ·

DOI 10.1055/s-2005-873020 • Published online February 1, 2006 .

ISSN 0172-4622 
on insulin sensitivity. Therefore, to study the (lack of) relationship between IMCL and insulin sensitivity upon endurance training, it is required to examine the longitudinal effects of endurance training on IMCL content. To this end, we recently examined insulin sensitivity and IMCL content in response to a short-term training program [40]. We found increased IMCL content after a short training period of two weeks that occurred in concert with a tendency to improved insulin sensitivity. As after two weeks of training, long-term adaptations are negligible, we concluded that IMCL content couldn't be directly responsible for insulin resistance.

As an alternative explanation for the relation between IMCL and insulin sensitivity, it has been suggested that not IMCL content per se, but a low fat oxidative capacity, which can result in the storage of IMCL, is responsible for the negative effects on insulin sensitivity $[11,16,35]$. Indeed, type 2 diabetes patients are characterized by low fat oxidative capacity [9], whereas endurance training results in increased IMCL levels along with increased fat oxidative capacity and improved insulin sensitivity.

In our short term training study, we observed that whole body fat oxidation, measured by indirect calorimetry during a threehour cycling test, was not (yet) changed. It is conceivable that changes on whole body level are not yet detectable, even though adaptations on subcellular (muscular) level already occurred. We here examine the effect of the acute exercise and the two week training intervention on gene expression of marker genes with a recognized key role in the skeletal muscle metabolic pathways for fat oxidation.

In addition, markers of glucose metabolism were also investigated to examine whether two weeks of training already improved glucose metabolism.

\section{Methods}

\section{Subjects}

Nine young, untrained and healthy male subjects (age [y] [mean \pm stdev.]: $23.3 \pm 3.2$; body mass [kg] [mean \pm stdev.]: $73.2 \pm 2.6$; BMI $\left[\mathrm{kg} / \mathrm{m}^{2}\right]$ [mean \pm stdev.]: $22.6 \pm 2.6$; maximal power output $\left[\mathrm{W}_{\max }\right][\mathrm{W} / \mathrm{kg}][$ mean \pm stdev.]: $3.8 \pm 0.6$; maximal oxygen uptake $\left[\dot{V}_{2 \max }\right][1 / \mathrm{min}]$ [mean \pm stdev.]: $3.54 \pm 0.55$ ) participated in this study. Subjects were recruited by advertisement and were excluded from participation if they had performed aerobic exercise competitively for more than three months or were still exercising on a regular basis. The institutional Medical Ethics Committee approved the study. Subjects gave their written informed consent after the nature of the procedure was explained.

\section{Experimental protocol}

A week preceding the experimental trial, an incremental test to determine $\mathrm{W}_{\max }$ and $\dot{\mathrm{VO}}_{2 \max }$ was performed, which was repeated in the week after the experimental trial.

The set up of the trial was as follows. Days $1-3$ formed a standardization period, during which a standardized diet was provided and subjects refrained from exercise. In the afternoon of day 3 , a three-hour cycling test was performed, where subjects cycled at $40 \%$ of their predetermined $\mathrm{W}_{\max }$. Muscle biopsies were taken from the vastus lateralis muscle before and after exercise and immediately frozen in liquid nitrogen. Biopsy samples used for immuno-fluorescence assays were embedded in Tissue-Tek (Sakura Finetek, Zoeterwoude, The Netherlands) and frozen in liquid nitrogen-cooled isopentane. Subjects then participated in a training program with a mixture of endurance- and interval training. Resting days were incorporated on day 4 and 10 . Days 15 to 17 were again used as a standardization period, with the same standardization diet as on day 1 to 3 and with subjects refraining from exercise. In the afternoon of day 17, subjects again cycled for 3 hours at $40 \% \mathrm{~W}_{\max }$. Again, biopsies were taken from the vastus lateralis muscle before and after exercise and immediately frozen.

\section{Diets}

The macronutrient composition of the diets during the three-day standardized period was such that $30 \%$ of the energy was consumed as fat, $55 \%$ as carbohydrate and $15 \%$ as protein. Subjects were given a fixed amount of food (1.65 times the basal metabolic rate based on Harris and Benedict equations [18]) and were asked to eat all the food provided, and nothing else. The diet consisted of breakfast, lunch, ready to use dinner and snacks.

The fat intake was (mean \pm stdev.): $103 \pm 8 \mathrm{~g}$ and $100 \pm 5 \mathrm{~g}$ on the first two days and $54 \pm 6 \mathrm{~g}$ on the third (half) day. The last meal before the exercise test consisted of sandwiches and provided (mean \pm stdev.) $3399 \pm 174 \mathrm{~J}$ of energy, $30 \pm 3 \mathrm{~g}$ of fat, $112 \pm 7 \mathrm{~g}$ of carbohydrate and $25 \pm 0 \mathrm{~g}$ of protein.

\section{Procedures \\ Incremental maximal test}

A week preceding the trial, the maximal performance $\left(\mathrm{W}_{\max }\right)$ and the maximal oxygen consumption $\left(\mathrm{V}_{2 \text { max }}\right)$ were determined. To this end, workload and oxygen consumption (Oxycon- $\beta$, Mijnhardt, Mannheim, Germany) were registered during an incremental exhaustive incremental exercise test on an electronically braked cycle ergometer (Lode, Groningen, The Netherlands).

\section{Three-hour cycling test}

The exercise test consisted of three hours of cycling on an electromagnetically braked ergometer at an intensity of $40 \%$ of the predetermined $\mathrm{W}_{\max }$. To facilitate the completion of the exercise test, subjects twice received $125 \mathrm{ml}$ of a maltodextrine drink (Extran Fresh Citrus; $131 \mathrm{~kJ} / 31 \mathrm{kcal}, 7,9 \mathrm{~g}$ CHO, $0 \mathrm{~g}$ proteins and lipids per $100 \mathrm{ml}$ ) during the second half of the test (at $t=90 \mathrm{~min}$. and $t=135$ min.). Subjects were allowed to drink water ad libitum during the whole test.

\section{Training program}

From day 5 to 14 , subjects reported to the laboratory daily to follow supervised training sessions on cycle ergometers, except for the resting day on day 10 . Training consisted of alternating days of interval- and endurance training and always started with 7.5 minutes of warming up at $40 \% \mathrm{~W}_{\max }$ and ended with 7.5 minutes of cooling down at $40 \% \mathrm{~W}_{\max }$. On days 5, 7, 9 and 11, cycling interval training was performed, which consisted of 45 minutes of alternating three minutes intervals at $70 \% \mathrm{~W}_{\max }$ and $35 \% \mathrm{~W}_{\max }$. At days $6,8,12$ and 14 , exercise consisted of 35 minutes at $55 \%$ 
$\mathrm{W}_{\text {max }}$, followed by 35 minutes at $50 \% \mathrm{~W}_{\max }$, and 35 minutes at $45 \% \mathrm{~W}_{\max }$, for a total duration of 120 minutes.

\section{Muscle biopsy sampling and analysis}

Muscle biopsies were taken from the mid-thigh region from $\mathrm{M}$. vastus lateralis according to the technique of Bergström [8]. The biopsy was used for isolation of total RNA using the acid phenol method of Chomozynski \& Sacchi [12], with acid Phenol extraction and Ethanol precipitation. The mRNA levels of lipoprotein lipase (LPL), hormone-sensitive lipase (HSL), hexokinase II (HKII), glucose transporter-4 (GLUT-4) and acetyl CoA carboxylase (ACC2) were quantified by RT-competitive PCR [4]. For the assays, the reverse transcription reaction was performed from $0.2 \mu \mathrm{g}$ of skeletal muscle total RNA in the presence of a thermostable reverse transcriptase (Tth, Promega, Madison, WI, USA) by use of one of the specific antisense primers. The competitive PCR assays were performed as previously described [3,29,32]. To improve the quantification of the amplified products, fluorescent dye-labeled sense oligonucleotides were used. The PCR products were separated and analyzed on an ALFexpress DNA sequencer (Amersham Pharmacia Biotech, San Francisco, CA, USA) with the Fragment Manager Software. Total RNA preparations and RT-competitive PCR assays of all four skeletal muscle samples from the same individual (before and after exercise and before and after training) were performed simultaneously.

Subcellular localization of GLUT-4 was performed by indirect immuno-fluorescence assays using an affinity-purified polyclonal rabbit antibody (GLUT4-BW) [10]. In short, multiple serial sections $(5 \mu \mathrm{m})$ from biopsies were collected and thaw mounted together on uncoated glass slides. After methanol/aceton fixation, the sections were incubated with the primary and appropriate secondary antibodies with multiple PBS washing steps in between. We determined sarcolemmal and sarcoplasmatic GLUT- 4 content and the basement membrane protein laminin (2E8, Dev. Hybridoma Study Bank, Iowa City, IA, USA) was used to identify the cellular border. The antibodies against GLUT-4 and laminin were used simultaneously in a double-staining. Stained sections were examined using a Nikon E800 fluorescence microscope (Uvikon, Bunnik, The Netherlands). All samples from the same individual were treated identically with regard to dilution of the antibody, incubation time and camera settings (exposure time and gain). Quantitative image analysis was performed by using LUCIA G/F image analysis software (Nikon, Düsseldorf, Germany). Using the laminin staining, a binary overlay was created by interactive thresholding. The binary was used to measure the intensity of the RGB signals from individual muscle fibers. A second binary was created by stepwise eroding the first binary from the edges, so that this second binary could be used to measure the intensity from the cytosol of the individual muscle fibers. In this way we were able to compute the ratio of GLUT-4 present in the sarcolemma over the GLUT-4 present in the sarcoplasma.

Due to insufficient quality of some coupes, coupes from only six subjects could be analyzed.

\section{Statistics}

Results are reported as mean \pm standard error of the mean (SEM). Statistical analyses were performed with SPSS for Windows 10.0.0 software (SPSS Inc., Chicago, Illinois, USA). Differences before and after training and before and after exercise were detected with paired student $t$-tests. Results were considered significant if $\mathrm{p}<0.05$.

\section{Results}

\section{Earlier analysis}

The following data was reported earlier: Blood samples were taken before and after training in the fasted state and during exercise, substrate oxidation was measured during exercise, insulin sensitivity was measured before and after training, using an insulin tolerance test and IMCL content was determined using proton magnetic resonance spectroscopy [40].

Fat oxidation gradually increased and carbohydrate oxidation decreased during the three-hour cycling test. There were no significant differences in the total fat- and carbohydrate oxidation after training compared to before training [40].

Before training, the three-hour cycling test decreased the IMCL signal by $14 \pm 3 \%(p<0.01)$. After training, the decrease in IMCL content during the three-hour cycling test was similar $(14 \%$ $\pm 9 \%$ ), but this decrease did not reach significance. Training increased the IMCL content significantly by $42 \pm 14 \%$ (IMCL content was $0.35 \pm 0.02 \%$ and $0.49 \pm 0.04 \%$ of the water reference signal, before and after training respectively) [40].

\section{Gene expression}

ACC2 mRNA tended to decrease during the three-hour cycling exercise after training $(-24.4 \%,[p=0.06])$ but not before training. Pre-exercise ACC2 mRNA concentrations were significantly decreased by $29.1 \%$ after training $(p=0.016)$ (Fig. 1 a).

HSL mRNA concentrations decreased with acute exercise after training $(-37.3 \%, \mathrm{p}=0.002)$, but not before training. Pre-exercise HSL mRNA concentrations were unchanged after training (Fig. 1 b).

LPL mRNA concentrations tended to increase with acute exercise before training $(+42.4 \%, \mathrm{p}=0.05)$, but not after training and preexercise LPL mRNA concentrations did not change with training (Fig. 1c).

HKII mRNA concentrations increased with the three-hour cycling exercise before training $(+72.5 \%, \mathrm{p}=0.03)$, and tended to increase after training (+99.3\%, p = 0.05) (Fig. 2a), but pre-exercise values did not differ before and after training.

GLUT-4 mRNA concentrations remained unchanged with acute exercise and with training (Fig. 2 b).

\section{GLUT-4 association with the membrane}

GLUT-4 association with the membrane increased by $17 \%$ in response to acute exercise after training $(p=0.015)$ and tended to increase by $8 \%$ before training $(p=0.09)$. After training, not more GLUT-4 was associated with the membrane than before (Fig. 3). 

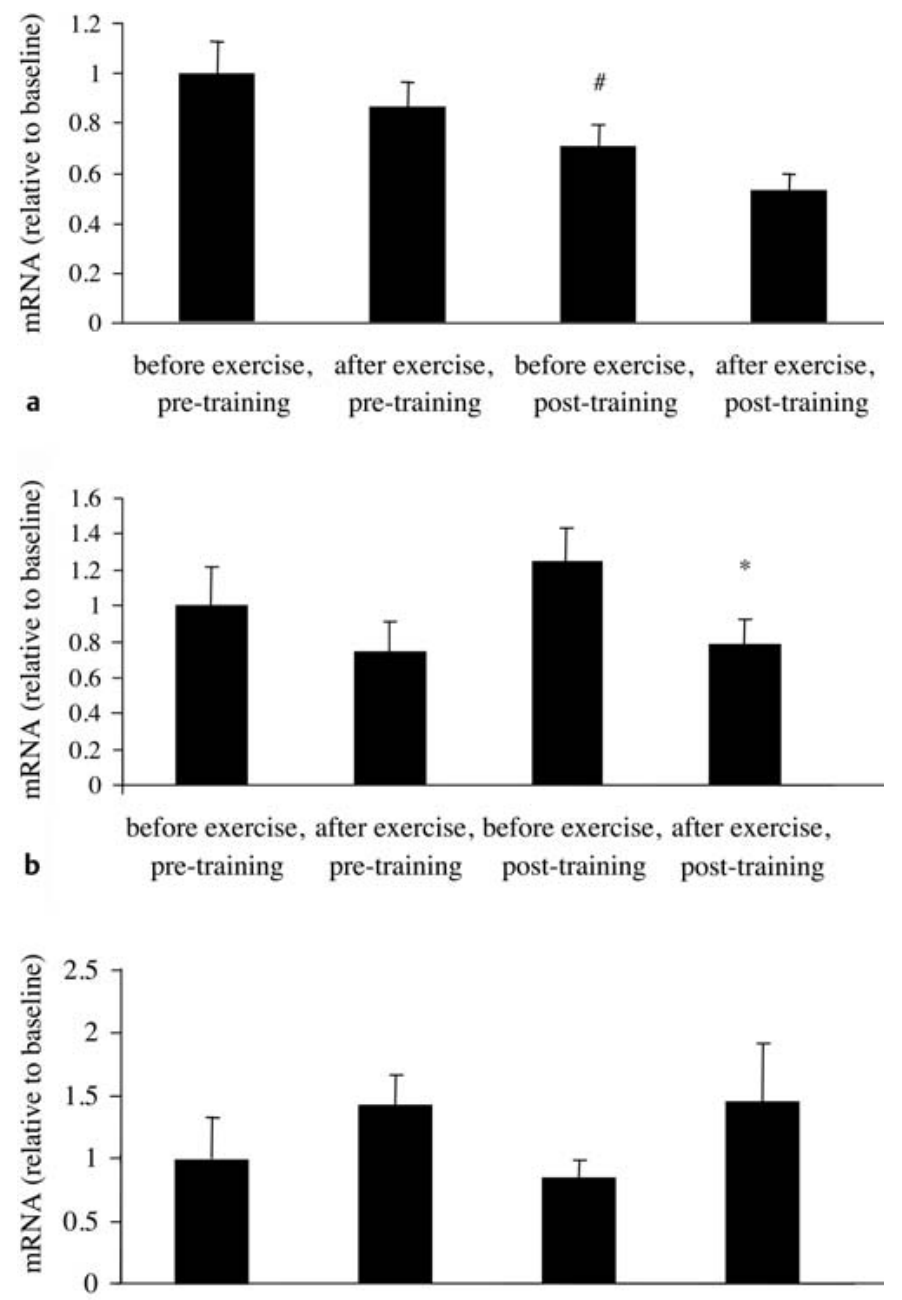

c pre-training pre-training post-training post-training

Fig. 1 a to c Muscle mRNA concentrations of ACC2 (a), HSL (b) and LPL (c) during training study, $n=9$. * Significantly different from before exercise, \# Significantly different from before training.

\section{Discussion}

It has been suggested that IMCL content is a marker of insulin resistance $[16,23,27,34]$, however, there is accumulating evidence that not the IMCL but rather intermediates of fat oxidation, such as Acyl-CoA and diacylglycerol (DAG), interfere with insulin signaling $[14,24]$. If this holds true, the balance between oxidative capacity and availability of FA is an important determinant in the development of insulin resistance. In line with this are recent results showing that overexpression of CPTI in myotubes increases $\beta$-oxidation and simultaneously increases insulin sensitivity without changing triglyceride content [35]. We reported earlier that a two-week training program increased IMCL content with a tendency towards improved insulin sensitivity. However, no change in whole body fat oxidation was detected. To examine whether an adaptive response was detectable on muscular level, marker genes for fat oxidation were investigated in biopsy samples. To this purpose mRNA concentrations of ACC2, HSL and LPL were quantified.

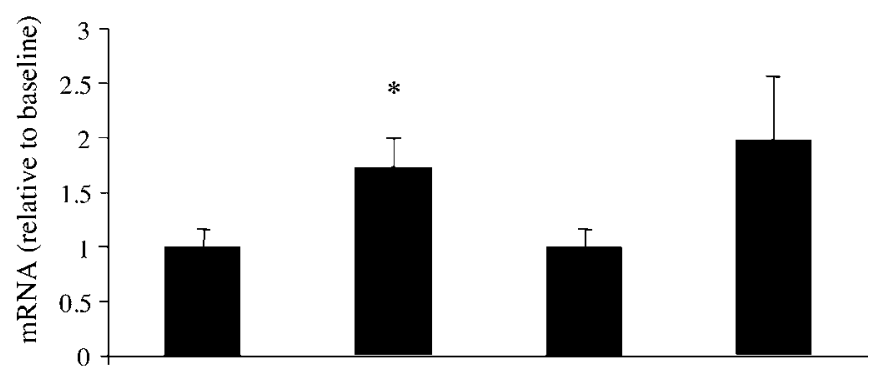

before exercise, after exercise, before exercise, after exercise, a pre-training pre-training post-training post-training

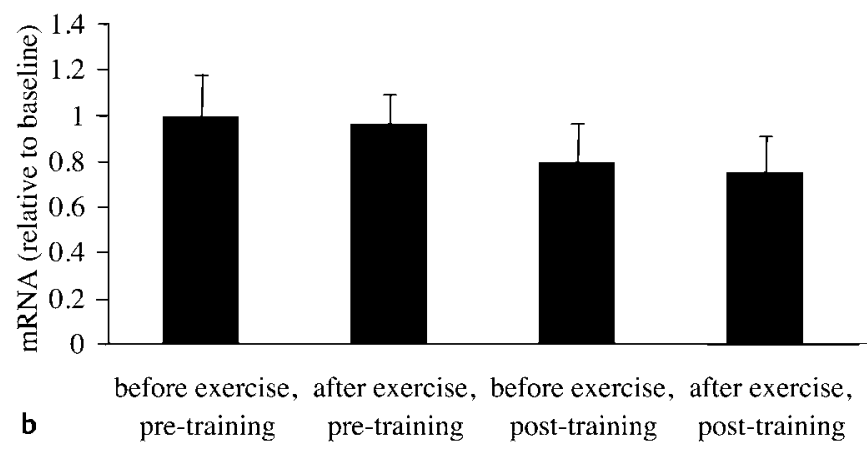

Fig. $\mathbf{2} \mathbf{a}$ and $\mathbf{b}$ Muscle mRNA concentrations of HKII (a) and GLUT-4 (b) during training study, $\mathrm{n}=9$. ${ }^{*}$ Significantly different from before exercise.

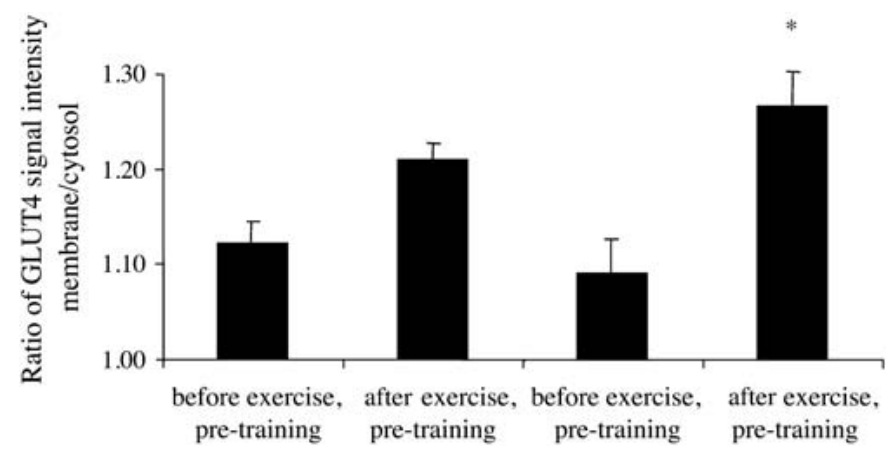

Fig. 3 Association of GLUT-4 with the membrane during training study (ratio of signal intensity at membrane over signal intensity in cytosol), $\mathrm{n}=6$. * Significantly different from before exercise.

ACC2 mRNA concentration tended to decrease in response to acute exercise after training and decreased in response to training, in the present study. ACC2 has been suggested to control the rate of fatty acid oxidation in muscles [1], where it catalyses the carboxylation of acetyl-CoA to form malonyl-CoA which inhibits carnitine-palmitoyl-transferase I (CPTI). CPTI catalyses the conjugation of acyl-CoA to carnitine, a process which is mandatory for the transport of long chain fatty acids into mitochondria. This step has been shown to be rate-limiting for fatty acid oxidation and therefore, the activity of CPTI plays a regulatory role in fat oxidation. Therefore, ACC2 has been suggested to play a pivotal role in the inhibition of fat oxidation. This notion is substantiated by observations in ACC2 knock-out mice showing 30\% higher fat oxidation rates compared to wild-type mice [2]. In accordance, albeit at the mRNA level, we recently showed that three months of low intensity training decreased ACC2 mRNA levels by $36 \%$ accompanied with increased fat oxidation [39]. Therefore, the tendency of ACC2 mRNA concentration to decrease with acute exer- 
cise after training indicates that a single endurance exercise session can already trigger the adaptive gene-regulatory response resulting in improved fat oxidative capacity which is a characteristic adaptation following consecutive bouts of endurance exercise. Although we did not (yet) find significant changes in whole body fat oxidation with the current training protocol of two weeks [40], the lowered ACC2 gene expression after training indicates that the initial steps towards improved fat oxidation are detectable at a cellular level within two-weeks of exercise training. The cumulative effect of acute exercise, performed daily during two weeks, seems to produce a true training effect, still measurable more than 48 hours after the last exercise bout.

While the decrease in ACC2 mRNA suggests increased fat oxidation, it does not give hints towards the source of the fat used. LPL is necessary to take up and hydrolyze VLDL from plasma [30] and therefore, LPL gene expression can be used as a marker for VLDL lipid oxidation. LPL mRNA concentrations tended to increase after acute exercise before training in the current study, but the short term training program did not yet result in detectable changes in LPL gene expression. We previously showed that after three months of training, LPL mRNA content tended to be increased [39]. This is in accordance with higher LPL mRNA concentration in trained subjects [38] and higher LPL activity in rodents after training $[5,33]$. The present two-week training study is probably not long enough to induce changes in LPL mRNA content.

The oxidation of IMCL could be an alternative and directly available source of fat for oxidation. As in adipose tissue, triglyceride hydrolysis is catalyzed by HSL. While the regulation of hydrolysis of IMCL is an emerging field of research, the information about the regulation of HSL during exercise and the effect of exercise training is still fragmentary. HSL is thought to regulate the hydrolysis of IMCL in skeletal muscle $[28,41]$ and therefore, it might be used as a marker of IMCL use. This notion is underscored by reports showing HSL activation upon contractile activity $[28,41]$.

While Hurley et al. reported increased utilization of intramuscular triglycerides during exercise in the trained state [21], Bergman et al did not find this [7]. In the present study, no change in HSL mRNA concentration was observed after 2 weeks of endurance training, which is in line with our results from ${ }^{1} \mathrm{H}-\mathrm{MRS}$, showing that the decrease in IMCL during exercise was similar before and after the current two week training program. In line with this are results from rat muscle, showing that HSL protein content did not change after training [15]. In contrast to what was anticipated, HSL mRNA concentrations decreased in response to acute exercise after the training period. This is surprising as IMCL content clearly decreased during exercise. This might suggest that other lipases are involved in IMCL hydrolysis. To our knowledge there is no other data on HSL gene expression in response to acute exercise.

Glucose disposal in response to insulin tended to be improved after a two-week training period and therefore, we also investigated markers of glucose metabolism. To this end, the expression of two genes involved in regulatory steps of glucose metabolism, i.e., GLUT-4, the major glucose transporter in skeletal muscle and
HKII, which catalyzes the phosphorylation of glucose to glucose6-phosphate, a rate limiting step for glucose utilization, were examined.

HKII mRNA increased with acute exercise, which has been reported before [25]. However, this marker of carbohydrate metabolism did not change by two weeks of training. GLUT-4 mRNA expression did not change with acute exercise, however more GLUT-4 protein was associated with the membrane after exercise after training. Before training, this effect was present as a tendency $(p=0.09)$. Others have reported increased GLUT- 4 protein content after training $[17,20,26,36]$, however the training protocols were longer and/or at a higher intensity than the protocol of the present study, which might explain why we did not find an increase of GLUT-4 mRNA in the current study. Richter and colleagues investigated the translocation of GLUT- 4 to the sarcolemma in response to acute exercise with different methodology, but also found an increased translocation after acute exercise [37]. However, the authors reported that translocation was diminished after 3 weeks of high intensity training, a response that we did not detect with the current training protocol.

The increased IMCL content after 2 weeks of training, with insulin sensitivity tending to be increased, is paralleled by a decrease in ACC2 mRNA expression, which indicates increased fat oxidative capacity on muscle level. Therefore, the results of the current study are in line with the hypotheses that the balance between FA oxidative capacity and availability is important for insulin sensitivity of skeletal muscle. Interestingly, it was recently shown that high-fat feeding to wild type mice resulted in the development of a diabetic phenotype, whereas ACC2 knock out mice were resistant against this high-fat induced obesity and diabetes [2].Our results are in concordance with an important role for ACC2 in determining the effect of IMCL on insulin sensitivity. Future research is needed to improve our understanding of the role that ACC2 is playing in the pathogenesis of diabetes.

In conclusion, the increase in IMCL content after a two-week training program, which resulted in a tendency of improved insulin sensitivity, was accompanied by molecular adaptations in muscle to improve fat oxidative capacity.

\section{Acknowledgements}

We would like to thank Niels Boon and Steven Constandse for practical help with the study. We would also like to thank Dr. H. Vidal (INSERM U.449, R. Laennec Faculty of Medicine, Claude Bernard University of Lyon) for kindly providing the competitors and Dr. H. Keizer (Dept. Movement Sciences, Maastricht University) for kindly providing the polyclonal GLUT4-BW antibody.

\section{Grants}

Dr. P. Schrauwen was supported by a grant from the Royal Netherlands Academy of Arts and Sciences (KNAW). 


\section{References}

${ }^{1}$ Abu-Elheiga L, Matzuk MM, Abo-Hashema KA, Wakil SJ. Continuous fatty acid oxidation and reduced fat storage in mice lacking acetylCoA carboxylase 2. Sci 2001; 291: 2613-2616

2 Abu-Elheiga L, Oh W, Kordari P, Wakil SJ. Acetyl-CoA carboxylase 2 mutant mice are protected against obesity and diabetes induced by high-fat/high-carbohydrate diets. Proc Natl Acad Sci USA 2003; 100: 10207-10212

${ }^{3}$ Andreelli F, Laville M, Vega N, Riou JP, Vidal H. Regulation of gene expression during severe caloric restriction: lack of induction of $\mathrm{p} 85$ alpha phosphatidylinositol 3-kinase mRNA in skeletal muscle of patients with type II (non-insulin-dependent) diabetes mellitus. Diabetologia 2000; 43: 356-363

${ }^{4}$ Auboeuf D, Vidal H. The use of the reverse transcription-competitive polymerase chain reaction to investigate the in vivo regulation of gene expression in small tissue samples. Anal Biochem 1997; 245: $141-148$

${ }^{5}$ Bagby GJ, Johnson JL, Bennett BW, Shepherd RE. Muscle lipoprotein lipase activity in voluntarily exercising rats. J Appl Physiol 1986; 60: $1623-1627$

${ }^{6}$ Baumann H, Jaggi M, Soland F, Howald H, Schaub MC. Exercise training induces transitions of myosin isoform subunits within histochemically typed human muscle fibres. Pflugers Arch 1987; 409: 349-360

7 Bergman BC, Butterfield GE, Wolfel EE, Casazza GA, Lopaschuk GD, Brooks GA. Evaluation of exercise and training on muscle lipid metabolism. Am J Physiol 1999; 276: E106-E117

${ }^{8}$ Bergstrom J, Hermansen L, Hultman E, Saltin B. Diet, muscle glycogen and physical performance. Acta Physiol Scand 1967; 71: 140-150

${ }^{9}$ Blaak EE, van Aggel-Leijssen DP, Wagenmakers AJ, Saris WH, van Baak MA. Impaired oxidation of plasma-derived fatty acids in type 2 diabetic subjects during moderate-intensity exercise. Diabetes 2000; 49: $2102-2107$

${ }^{10}$ Borghouts LB, Schaart G, Hesselink MK, Keizer HA. GLUT-4 expression is not consistently higher in type- 1 than in type- 2 fibres of rat and human vastus lateralis muscles; an immunohistochemical study. Pflugers Arch 2000; 441: 351 - 358

11 Bruce CR, Anderson MJ, Carey AL, Newman DG, Bonen A, Kriketos AD, Cooney GJ, Hawley JA. Muscle oxidative capacity is a better predictor of insulin sensitivity than lipid status. J Clin Endocrinol Metab 2003; 88: $5444-5451$

12 Chomczynski P, Sacchi N. Single-step method of RNA isolation by acid guanidinium thiocyanate-phenol-chloroform extraction. Anal Biochem 1987; 162: 156-159

13 Decombaz J, Schmitt B, Ith M, Decarli B, Diem P, Kreis R, Hoppeler H, Boesch C. Postexercise fat intake repletes intramyocellular lipids but no faster in trained than in sedentary subjects. Am J Physiol Regul Integr Comp Physiol 2001; 281: R760-R769

14 Dresner A, Laurent D, Marcucci M, Griffin ME, Dufour S, Cline GW, Slezak LA, Andersen DK, Hundal RS, Rothman DL, Petersen KF, Shulman GI. Effects of free fatty acids on glucose transport and IRS-1-associated phosphatidylinositol 3-kinase activity. J Clin Invest 1999; 103: $253-259$

15 Enevoldsen LH, Stallknecht B, Langfort J, Petersen LN, Holm C, Ploug T, Galbo $\mathrm{H}$. The effect of exercise training on hormone-sensitive lipase in rat intra-abdominal adipose tissue and muscle. J Physiol 2001; 536: $871-877$

${ }^{16}$ Goodpaster BH, He J, Watkins S, Kelley DE. Skeletal muscle lipid content and insulin resistance: evidence for a paradox in endurancetrained athletes. J Clin Endocrinol Metab 2001; 86: 5755-5761

${ }^{17}$ Gulve EA, Spina RJ. Effect of 7-10 days of cycle ergometer exercise on skeletal muscle GLUT-4 protein content. J Appl Physiol 1995; 79: $1562-1566$

${ }^{18}$ Harris JA, Benedict FG. A Biometric Study of Basal Metabolism in Man. Washington: Carnegie Institution of Washington, 1919

19 Hoppeler H, Howald H, Conley K, Lindstedt SL, Claassen H, Vock P, Weibel ER. Endurance training in humans: aerobic capacity and structure of skeletal muscle. J Appl Physiol 1985; 59: 320-327.

${ }^{20}$ Houmard JA, Shinebarger MH, Dolan PL, Leggett-Frazier N, Bruner RK, McCammon MR, Israel RG, Dohm GL. Exercise training increases GLUT-4 protein concentration in previously sedentary middle-aged men. Am J Physiol 1993; 264: E896-E901
${ }^{21}$ Hurley BF, Nemeth PM, Martin WH 3rd, Hagberg JM, Dalsky GP, Holloszy JO. Muscle triglyceride utilization during exercise: effect of training. J Appl Physiol 1986; 60: 562-567

22 Ingjer $\mathrm{F}$. Effects of endurance training on muscle fibre ATP-ase activity, capillary supply and mitochondrial content in man. J Physiol 1979; 294: 419-432

23 Jacob S, Machann J, Rett K, Brechtel K, Volk A, Renn W, Maerker E, Matthaei S, Schick F, Claussen CD, Haring HU. Association of increased intramyocellular lipid content with insulin resistance in lean nondiabetic offspring of type 2 diabetic subjects. Diabetes 1999; 48: $1113-$ 1119

${ }^{24}$ Kelley DE, Mandarino LJ. Fuel selection in human skeletal muscle in insulin resistance: a reexamination. Diabetes 2000; 49: 677-683

${ }^{25}$ Kraniou Y, Cameron-Smith D, Misso M, Collier G, Hargreaves M. Effects of exercise on GLUT-4 and glycogenin gene expression in human skeletal muscle. J Appl Physiol 2000; 88: 794-796

${ }^{26}$ Kristiansen S, Gade J, Wojtaszewski JF, Kiens B, Richter EA. Glucose uptake is increased in trained vs. untrained muscle during heavy exercise. J Appl Physiol 2000; 89: 1151 - 1158

27 Krssak M, Falk Petersen K, Dresner A, DiPietro L, Vogel SM, Rothman DL, Roden M, Shulman GI. Intramyocellular lipid concentrations are correlated with insulin sensitivity in humans: a 1H NMR spectroscopy study. Diabetologia 1999; 42: $113-116$

28 Langfort J, Donsmark M, Ploug T, Holm C, Galbo H. Hormone-sensitive lipase in skeletal muscle: regulatory mechanisms. Acta Physiol Scand 2003; 178: $397-403$

${ }^{29}$ Laville M, Auboeuf D, Khalfallah Y, Vega N, Riou JP, Vidal H. Acute regulation by insulin of phosphatidylinositol-3-kinase, Rad, Glut 4, and lipoprotein lipase mRNA levels in human muscle. J Clin Invest 1996; 98: $43-49$

${ }^{30}$ Levak-Frank S, Radner H, Walsh A, Stollberger R, Knipping G, Hoefler G, Sattler W, Weinstock PH, Breslow JL, Zechner R. Muscle-specific overexpression of lipoprotein lipase causes a severe myopathy characterized by proliferation of mitochondria and peroxisomes in transgenic mice. J Clin Invest 1995; 96: 976-986

${ }^{31}$ Martin WH 3rd. Effects of acute and chronic exercise on fat metabolism. Exerc Sport Sci Rev 1996; 24: 203 - 231

32 Millet L, Vidal H, Andreelli F, Larrouy D, Riou JP, Ricquier D, Laville M, Langin D. Increased uncoupling protein-2 and -3 mRNA expression during fasting in obese and lean humans. J Clin Invest 1997; 100 : $2665-2670$

33 Oscai LB, Caruso RA, Wergeles AC. Lipoprotein lipase hydrolyzes endogenous triacylglycerols in muscle of exercised rats. J Appl Physiol 1982; 52: 1059-1063

${ }^{34}$ Pan DA, Lillioja S, Kriketos AD, Milner MR, Baur LA, Bogardus C, Jenkins AB, Storlien LH. Skeletal muscle triglyceride levels are inversely related to insulin action. Diabetes 1997; 46: 983 - 988

35 Perdomo G, Commerford SR, Richard AM, Adams SH, Corkey BE, O'Doherty RM, Brown NF. Increased beta-oxidation in muscle cells enhances insulin-stimulated glucose metabolism and protects against fatty acid-induced insulin resistance despite intramyocellular lipid accumulation. J Biol Chem 2004; 279: 27177-27186

36 Phillips SM, Han XX, Green HJ, Bonen A. Increments in skeletal muscle GLUT-1 and GLUT-4 after endurance training in humans. Am J Physiol 1996; 270: E456-E462

${ }^{37}$ Richter EA, Jensen P, Kiens B, Kristiansen S. Sarcolemmal glucose transport and GLUT-4 translocation during exercise are diminished by endurance training. Am J Physiol 1998; 274: E89-E95

38 Schmitt B, Fluck M, Decombaz J, Kreis R, Boesch C, Wittwer M, Graber F, Vogt M, Howald H, Hoppeler H. Transcriptional adaptations of lipid metabolism in tibialis anterior muscle of endurance-trained athletes. Physiol Genomics 2003; 15: 148-157

39 Schrauwen P, van Aggel-Leijssen DP, Hul G, Wagenmakers AJ, Vidal H, Saris WH, van Baak MA. The effect of a 3-month low-intensity endurance training program on fat oxidation and acetyl-CoA carboxylase-2 expression. Diabetes 2002; 51: 2220-2226

40 Schrauwen-Hinderling VB, Schrauwen P, Hesselink MK, van Engelshoven JM, Nicolay K, Saris WH, Kessels AG, Kooi ME. The increase in intramyocellular lipid content is a very early response to training. J Clin Endocrinol Metab 2003; 88: 1610-1616

${ }^{41}$ Watt MJ, Heigenhauser GJ, O’Neill M, Spriet LL. Hormone-sensitive lipase activity and fatty acyl-CoA content in human skeletal muscle during prolonged exercise. J Appl Physiol 2003; 95: 314-321 